\title{
Pedagang Tradisional Sebagai Pelaku UMKM Mitra Usaha BMT Walisongo dalam Pembiayaan Produktif
}

\author{
Sokhikhatul Mawadah \\ UIN Walisongo \\ sokhikhatulmawadah@walisongo.ac.id
}

\begin{abstract}
The purpose of this study is to analyze how the role of BMT Walisongo is a provider of productive financing as a business partner for traditional merchant MSME in the Mijen market in terms of capital. Average traditional traders from the middle to lower classes, so they have not been able to overcome the problems of the needed capital. On the other hand the role of BMT in providing productive financing has very good potential for economic development, especially in the development of jobs for small and medium-sized communities, so as to be able to provide benefits that can be felt by the surrounding community. This study using descriptive qualitative methods by studying two sources, namely primary data and secondary data.
\end{abstract}

Keywords: BMT, MSME, business partner, productive financing

\begin{abstract}
Abstrak
Tujuan dari penelitian ini untuk menganalisis bagaimana peran BMT Walisongo penyedia pembiayaan produktif sebagai mitra usaha bagi UMKM pedagang tradisional di pasar Mijen dalam hal permodalan. Pedagang tradisional rata-rata dari kalangan menengah ke bawah, sehingga belum mampu mengatasi permasalahan modal usaha yang dibutuhkan. Di sisi lain peran BMT dalam penyediaan pembiayaan produktif memiliki potensi yang sangat baik bagi pembangunan perekonomian, terutama dalam pengembangan lapangan pekerjaan untuk masyarakat kecil dan menengah, sehingga mampu memberikan manfaat yang dapat dirasakan oleh masyarakat sekitar. Penelitian ini menggunakan metode kualitatif deskriptif dengan mengkaji dua sumber yaitu data primer dan data sekunder.
\end{abstract}

Kata Kunci: BMT, UMKM, Mitra Usaha, Pembiayaan Produktif

\section{PENDAHULUAN}

BMT adalah singkatan dari Baitul Maal wat Tamwil atau Balai Usaha Mandiri Terpadu. Kegiatan dari Baitul Tamwil sendiri adalah mengembangkan usahausaha produktif dan investasi dalam meningkatkan kualitas kegiatan ekonomi pengusaha kecil dengan antara lain mendorong kegiatan menabung dan menunjang kegiatan ekonominya. Kegiatan Baitul Maal sendiri kegiatannya adalah menerima dari dana zakat, infaq, shodaqoh, serta menjalankannya sesuai dengan peraturan dan amanahnya (Ismanto, 2015: 24). Selain itu Baitul Maal wat Tamwil (BMT) merupakan lembaga keuangan dengan konsep syariah yang lahir sebagai pilihan yang menggabungkan konsep maal dan tamwil dalam satu kegiatan lembaga. Konsep maal sendiri merupakan konsep yang merupakan bagian dari kegiatan kehidupan masyarakat muslim dalam hal menghimpun atau menyalurkan dana yang digunakan untuk zakat, infak, 
dan sedekah (ZIS) secara produktif. Sedangkan konsep tanwil sendiri merupakan sebagian kegiatan yang bisnis yang mirni untuk mendapatkan sebuah keuntungan atau laba terhadap sektor masyarakat menengah kebawah (mikro).

Kehadiran BMT di masyarakat diharapkan memberikan perubahan yang baik terutama masyarakat muslim, di saat kegiatan ekonomi masih menggunakan prinsip riba dalam support funding atau kegiatan masyarakat dalam mengembangkan kegiatan pemberdayaan usaha kecil dan menengah ataupun kegiatan ekonomi lainnya. Kehadiran lembaga keuangan mikro syariah yaitu BMT ini dirasa telah membawa manfaat bagi masyarakat, terutama bagi masyarakat kecil yang tidak bankable (nasabah yang tidak memenuhi persyaratan bank) serta yang menolak riba, karena berorientasi pada ekonomi kerakyatan. Selain itu kehadiran BMT menjadi jalan untuk melaksanakan misi ekonomi syariah dan di sisi lain mampu mengemban tugas ekonomi yaitu meningkatkan kegiatan ekonomi mikro. BMT bukan hanya sebuah lembaga yang berorientasi kegiatan bisnis saja akan tetapi berorientasi sosial, serta melakukan pendistribusian kekayaan secara adil dan merata. Hal ini yang menjadikan BMT berkembang cukup pesat di tengah-tengah masyarakat terutama masyarakat muslim jika dibandingkan lembaga keuangan syariah lainnya (Masyitoh, 2014: 18).

BMT sendiri dalam kegiatan keuangan digunakan untuk membantu pembiayaan usaha mikro kecil menengah. Sebuah usaha kecil dengan menggunakan dana yang kecil atau tidak besar. Definisi dari pembiayaan sendiri adalah kegiatan pendanaan yang dikeluarkan untuk mendukung investasi yang telah direncanakan, baik dilakukan sendiri maupun dijalankan oleh orang lain. Dalam BMT, pembiayaan merupakan salah satu fasilitas yang memberikan pinjaman bagi debitur atau calon anggota yang kekurangan dana untuk sebuah usaha dimana pihak debitur diwajibkan memberikan angsuran setiap jangka waktu tertentu dengan bagi hasil yang telah disepakati di awal persetujuan kedua belah pihak. Dalam pembiayaan sendiri ada dua sifat pembiayaan berdasarkan penggunaannya yaitu pembiayaan konsumtif dan produktif. Untuk pembahasaan di sini menggunakan pembiayaan produktif (riil) yaitu suatu pembiayaan yang ditujukan untuk kegiataan memenuhi kebutuhan produksi, sebuah kegiatan untuk peningkatan usaha, baik usaha produksi, perdagangan, maupun investasi (Adiwarman, 2010: 234).

Dalam menjalankan tugasnya, KSPPS Walisongo bergerak dalam bidang KSPPS (Koperasi Simpan Pinjam Pembiayaan Syariah). Hal ini terlihat dari kegiatan yang dijalankan sehari-hari di KSPPS BMT Walisongo Semarang yaitu menghimpun dana dari masyarakat dalam bentuk pendanaan dan menyalurkan dana kepada masyarakat dalam bentuk pembiayaan.

Prastiawati et al., (2016) meneliti mengenai Peran Pembiayaan Baitul Maal Wat Tamwil Terhadap Perkembangan Usaha dan Peningkatan Kesejahteraan Anggotanya dari Sektor Mikro Pedagang Pasar Tradisional menunjukkan bahwa pembiayaan BMT pada pedagang pasar tradisional yang menjadi anggota BMT di Bantul, tidak berpengaruh signifikan terhadap persepsi 
pedagang tersebut tentang perkembangan usahanya dan peningkatan kesejahteraannya (walaupun arahnya sudah benar positif). Namun demikian, persepsi pedagang tersebut tentang perkembangan usahanya berpengaruh positif signifikan terhadap persepsi peningkatan kesejahteraannya.

Anggraeni et al., (2013) meneliti Akses UMKM Terhadap Pembiayaan Mikro Syariah dan Dampaknya Terhadap Perkembangan Usaha: Kasus BMT Tadbiirul Ummah, Kabupaten Bogor menghasilkan akses UMKM BMT terhadap perbankan jauh lebih kecil dibandingkan responden kontrol. Sebagian besar UMKM BMT menjadikan BMT sebagai lembaga keuangan komplementer dengan perbankan formal (66,67\%). Rata-rata jumlah pinjaman dan simpanan responden BMT lebih kecil dari UMKM control yaitu Rp 2,92 juta dan Rp 11,94 juta. Faktor-faktor yang mempengaruhi akses UMKM terhadap pembiayaan mikro syariah dari BMT adalah variabel dummy akses simpanan, umur pengusaha UMKM, dummy jenis usaha 2 (manufaktur), serta omset usaha dengan nilai odds ratio sebesar 17,514, 1,191, 26,353 dan 1,000. Pembiayaan mikro syariah dari BMT berdampak positif terhadap perkembangan UMKM. Rata-rata keuntungan usaha mengalami peningkatan sebesar 6,21\% dari Rp 79,12 juta menjadi Rp 84,03 juta pertahun. Berdasarkan analisis OLS, faktor-faktor yang mempengaruhi nilai perkembangan keuntungan usaha UMKM adalah lama pendidikan, lama usaha, besarnya pembiayaan syariah BMT, dan besarnya kredit konvensional.

Hascaryani, Tyas D. et al., (2011) meneliti metafora risk and return sebagai dasar pengembangan baitul maal wa tamwil (BMT) yang mandiri menghasilkan beberapa hal yang dilakukan BMT untuk menyikapi hambatan dan tantangan menujuk kemandirian adalah penerapan sistem personal garansi, pelanggaran syarat yang bersifat administratif, menjalin hubungan dengan mendasarkan pada kesamaan keyakinan (religiusitas) pada target pasar yang potensial, dan pelayanan lebih selain penjaminan nasabah.

Dewi et al., (2017) meneliti peran pembiayaan mudharabah dalam pengembangan kinerja usaha mikro pada BMT menghasilkan tidak semua BMT menyediakan pembiayaan mudharabah karena masih banyaknya kekhawatiran terhadap pembiayaan mudharabah yang berisiko tinggi. Oleh karena itu, penerapan salah satu prinsip syariah yaitu pembiayaan mudharabah masih tergolong sangat rendah pada BMT di Indonesia.

Dari keempat penelitian terdahulu yang dapat penulis simpulkan adalah rendahnya pembiayaan bagi pengusaha skala UMKM, tidak meratanya pendapatan masyarakat, kemampuan manajemen UMKM kurang memadai terlebih dalam hal pencatatan keuangannya, monopoli BMT pada sektor mikro (BMT masih terpusat pada masyarakat menengah ke atas dalam hal pembiayaan permodalan dibanding masyarakat menengah ke bawah). Hal yang membedakan penelitian penulis dari keempat penelitian terdahulu adalah peran maksimal dari KSPPS BMT Walisongo sebagai penyedia pembiayaan produktif riil dan juga sebagai rekan kerja UMKM pedagang di Pasar Mijen. Dari data yang didapat, penulis yakni hasil observasi dan wawancara di lapangan menunjukkan bahwa kinerja KSPPS BMT Walisongo 
mampu menjadi tonggak perekonomian sebagai rekan kerja pedangan di Pasar Mijen pada khususnya serta warga sekitar pada umumnya.

Sesuai dengan keterbatasan yang ada pada penulis dalam berbagai hal, maka penulis memberikan batasan pada peran BMT Walisongo penyedia pembiayaan produktif sebagai mitra usaha bagi pedagang tradisional di Pasar Mijen. Berangkat dari latar penulis yang telah dipaparkan di atas, dapat dirumuskan permasalahan penulis adalah bagaimana peran BMT Walisongo sebagai penyedia pembiayaan produktif dan peran BMT Walisongo sebagai mitra usaha pedagang tradisional di Pasar Mijen.

\section{KAJIAN LITERATUR}

\section{Teori BMT}

Berdasarkan Pinbuk Perwakilan Sumatera Utara, BMT adalah kependekan kata dari Balai Usaha Mandiri Terpadu atau Baitul Mal wat Tamwil, yaitu Lembaga Keuangan Mikro Syariah yang beroperasi berdasarkan prinsipprinsip syariah. BMT sesuai namanya terdiri dari dua fungsi utama, yaitu:

a. Baitul Tamwil (Rumah Pengembangan Harta), melakukan kegiatan pengembangan usaha-usaha produktif dan investasi dalam meningkatkan kulitas kegiatan ekonomi pengusaha mikro dan kecil dengan cara berikut, seperti mendorong kegiatan menabung dan pembiayaan kegiatan ekonomi.

b. Baitul Mal (Rumah Harta), menerima titipan dana zakat, infak, dan sedekah dan juga menyalurkan sesuai dengan peraturan dan amanatnya (PP 2017).

Dengan demikian keberadaan BMT dapat dipandang memiliki dua fungsi utama, yaitu sebagai media penyalur pendayagunaan harta ibadah, seperti zakat, infak, sedekah, dan wakaf, serta dapat pula berfungsi sebagai institusi yang bergerak di bidang investasi yang bersifat produktif sebagaimana layaknya bank. Selain itu BMT juga mengembangkan usaha di bidang sektor riil. Usaha sektor riil sendiri tidak boleh menyaingi usaha anggota, akan tetapi harus mendukung dan memperlancar proses kegiatan secara bersama akan keberhasilan usaha anggota berdasarkan jenis usahanya (Soemitra, 2017: 474).

Menurut (Al Arif, 2017: 319), keberadaan BMT setidaknya harus memiliki beberapa peran berikut:

1) Menjauhkan masyarakat dari praktik ekonomi nonsyariah, aktif melakukan sosialisasi di tengah masyarakat tentang arti pentingnya sistem ekonomi Islam. Hal ini bisa dilakukan dengan pelatihan-pelatihan mengenai cara-cara transaksi yang islami, misalnya bukti transaksi, dilarang mencurangi timbangan, jujur terhadap konsumen, dan sebagainya.

2) Melakukan pembinaan dan pendanaan usaha kecil. BMT harus bersikap aktif menjalankan fungsi sebagai lembaga keuangan mikro, misalnya dengan jalan pendampingan, pembinaan, penyuluhan, dan pengawasan, terhadap usaha-usaha nasabah atau masyarakat umum. 
3) Melepaskan ketergantungan pada rentenir. Masyarakat masih bergantung pada rentenir karena rentenir mampu memenuhi keinginan masyarakat dalam memenuhi dana dengan segera. Oleh karena itu, BMT harus mampu melayani masyarakat secara lebih baik, misalnya tersedia dana setiap saat, birokrasi yang sederhana, dan sebagainya.

4) Menjaga keadilan ekonomi masyarakat dengan distribusi yang merata. Karena langsung berhadapan dengan masyarakat yang kompleks, BMT dituntut harus pandai bersikap. Langkah-langkah untuk melakukan evaluasi dalam rangkan pemetaan skala prioritas yang harus diperhatikan, misalnya dalam masalah pembiayaan, BMT harus memerhatikan kelayakan nasabah dalam hal golongan nasabah dan jenis pembiayaan (Sudarsono, 2003: 104).

\section{Dasar Hukum BMT}

\section{a. Alquran}

Dalam Alquran tidak ada ayat yang secara lugas menyebutkan atau mensyariatkan adanya BMT penyedia pembiayaan produktif baik secara umum ataupun secara khusus. Namun ada beberapa ayat yang memberi petunjuk dan sampai saat ini dapat dijadikan sebagai landasan hukum Baitul Mal wat Tamwil (BMT) yaitu:

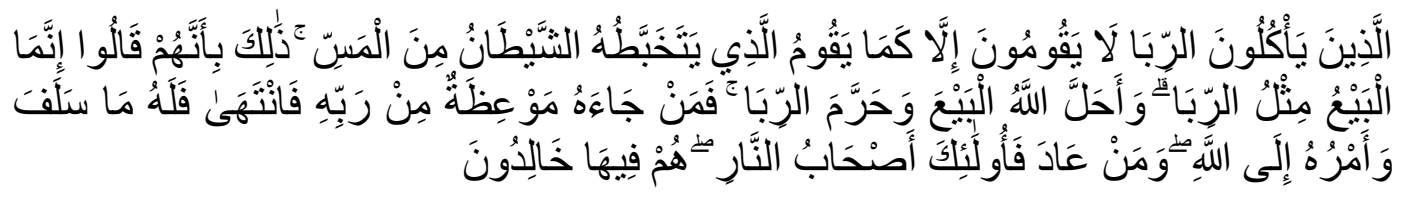

Artinya: "orang-orang yang makan (mengambil) riba tidak dapat berdiri melainkan seperti berdirinya orang yang kemasukan syaitan lantaran (tekanan) penyakit gila. Keadaan mereka yang demikian itu, adalah disebabkan mereka (berpendapat), sesungguhnya jual beli itu sama dengan riba, padahal Allah telah menghalalkan jual beli dan mengharamkan riba. Orang-orang yang telah sampai kepada larangan dari Tuhannya, lalu terus berhenti (dari mengambil riba), maka baginya apa yang telah diambilnya dahulu (sebelum datang larangan), dan urusannya (terserah) kepada Allah. Orang yang kembali (mengambil riba), maka orang itu adalah penghunipenghuni neraka, mereka kekal di dalamnya". (QS. Al-Baqarah Ayat 275).

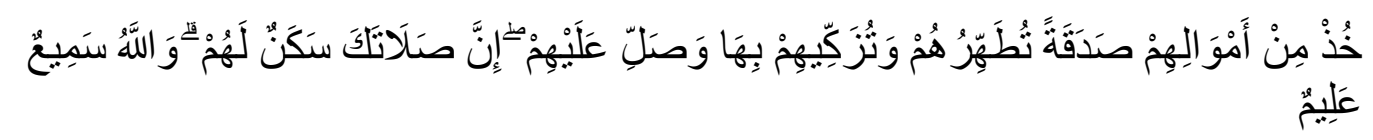

Artinya: "Ambillah zakat dari sebagian harta mereka dengan zakat itu kamu membersihkan dan mensucikan mereka dan berdoalah untuk mereka. Sesungguhnya doa kamu itu (menjadi) ketentraman jiwa bagi mereka. Dan Allah Maha mendengar lagi Maha Mengetahui. (QS. At-Taubah Ayat 103). 
b. Hadis

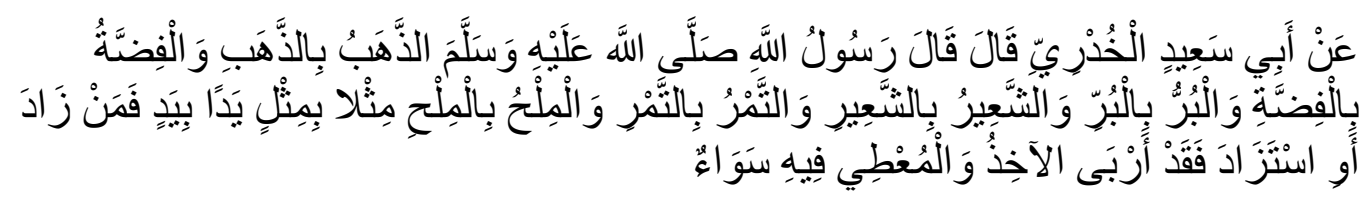

Artinya: "Diriwayatkan oleh Abu Said Al Khudri bahwa Rasulullah bersabda, "Emas hendaklah dibayar dengan emas, perak dengan perak, gandum dengan gandum, tepung dengan tepung, kurma dengan kurma, garam dengan garam, bayaran harus dari tangan ke tangan (cash). Barangsiapa memberi tambahan atau meminta tambahan, sesungguhnya ia telah berurusan dengan riba." Penerima dan pemberi sama-sama bersalah." (Shahih Muslim no. 2971, dalam Dewi, 2017: 100).

c. Peraturan Perundang-undangan

Adapun beberapa peraturan perundang-undangan yang mengatur tentang Baitul Mal wat Tamwil (BMT) yaitu diantaranya adalah sebagai berikut:

1) UU No.17 Tahun 2012.

2) UU No.1 Tahun 2013 tentang Lembaga Keuangan Mikro (UU LKM).

3) Peraturan Pemerintahan Nomor 89 Tahun 2014 tentang Suku Bunga Pinjaman atau Imbal Hasil Pembiayaan dan Luas Cakupan Wilayah Usaha Lembaga Keuangan Mikro.

4) Peraturan OJK (POJK) Nomor 12/POJK.05/2014 tentang Pembinaan dan Pengawasan Lembaga Keuangan Mikro.

5) Peraturan OJK (PJOK) Nomor 14/PJOK.05/2014 tentang Pembinaan dan Pengawasan Lembaga Keuangan Mikro (Soemitra, 2017: 478).

\section{Teori Usaha Mikro Kecil dan Menengah}

Usaha mikro, kecil dan menengah merupakan perusahaan ataupun usaha yang dimiliki oleh Warga Negara Indonesia (WNI), memiliki total aset tidak lebih dari Rp. 600 juta (di luar area perumaham dan perkebunan). UMKM termasuk sub sektor ekonomi yang banyak menyerap tenaga kerja dan banyak diminati oleh masyarakat berpenghasilan menengah ke bawah.

Menurut UUD 1945 kemudian dikuatkan melalui TAP MPR NO.XVI/MPRRI/1998 tentang Politik Ekonomi dalam Rangka Demokrasi Ekonoim, Usaha Mikro, Kecil, dan Menengah perlu diberdayakan sebagai bagian integral ekonomi rakyat yang mempunyai kedudukan, peran, potensi strategis untuk mewujudkan struktur perekonomian nasional yang makin seimbang, berkembang, dan berkeadilan. Menurut (Suci, 2017: 54) selanjutnya dibuatlah pengertian UMKM melalui UU No.9 Tahun 1999 dan karena keadaan perkembangan yang semakin dinamis diubah ke UU No.20 Pasal 1 Tahun 2008 tentang Usaha Mikro, Kecil dan Menengah maka pengertian UMKM adalah sebagai berikut: 
1. Usaha Mikro adalah usaha produktif milik orang perorangan dan/atau badan usaha perorangan yang memenuhi kriteria Usaha Mikro sebagaimana diatur dalam Undang-Undang ini.

2. Usaha Kecil adalah usaha ekonomi produktif yang berdiri sendiri, yang dilakukan oleh orang perorangan atau badan usaha yang bukan merupakan anak perusahaan atau bukan cabang perusahaan yang dimiliki, dikuasai, atau menjadi bagian baik langsung maupun tidak langsung dari usaha menengah atau usaha besar yang memenuhi kriteria Usaha Kecil sebagaimana dimaksud dalam Undang-Undang ini.

3. Usaha Menengah adalah usaha ekonomi produktif yang berdiri sendiri, yang dilakukan oleh orang perseorangan atau badan usaha yang bukan merupakan anak perusahaan atau cabang perusahaan yang dimiliki, dikuasai, atau menjadi bagian baik langsung maupun tidak langsung dengan usaha kecil atau usaha besar dengan jumlah kekayaan bersih atau hasil penjualan tahunan sebagaimana diatur dalam Undang- Undang.

Berdasarkan kekayaan dan hasil penjualan, menurut Undang-Undang Nomor 20 tahun 2008 pasal 6, kriteria usaha mikro yaitu:

1. Memiliki kekayaan bersih paling banyak Rp 50.000.000,00 (lima puluh juta rupiah) tidak termasuk tanah dan bangunan tempat usaha.

2. Memiliki hasil penjualan tahunan paling banyak Rp 300.000.000,00 (tiga ratus juta rupiah).

Menurut (LPPI 2015), kriteria usaha kecil adalah sebagai berikut:

1. Memiliki kekayaan bersih lebih dari Rp 50.000.000,00 (lima puluh juta rupiah) sampai dengan paling banyak $\mathrm{Rp} 500.000 .000,00$ (lima ratus juta rupiah) tidak termasuk tanah dan bangunan tempat usaha.

2. Memiliki hasil penjualan tahunan lebih dari Rp 300.000.000,00 (tiga ratus juta rupiah) sampai dengan paling banyak Rp 2.500.000.000,00 (dua milyar lima ratus juta rupiah).

Sedangkan kriteria usaha menengah adalah sebagai berikut:

1. Memiliki kekayaan bersih lebih dari Rp 500.000.000,00 (lima ratus juta rupiah) sampai dengan paling banyak Rp 10.000.000.000,00 (sepuluh milyar rupiah) tidak termasuk tanah dan bangunan tempat usaha.

2. Memiliki hasil penjualan tahunan lebih dari Rp 2.500.000.000,00 (dua milyar lima ratus juta rupiah) sampai dengan paling banyak Rp 50.000.000.000,00 (lima puluh milyar rupiah).

Menurut Badan Pusat Statistik (BPS) memberikan definisi UMKM berdasarkan kuantitas tenaga kerja. Usaha kecil merupakan usaha yang memiliki jumlah tenaga kerja 5 orang sampai dengan 19 orang. Sedangkan usaha menengah merupakan usaha yang memiliki jumlah tenaga kerja 20 orang sampai dengan 99 orang (Ariani dan Mohamad Nur Utomo, 2017: 100).

\section{Teori Kemitraan}

Menurut K. Wong C et al., (2007), kemitraan adalah strategi yang diciptakan untuk melibatkan pihak lain dalam bentuk partisipasi berdasarkan prinsip mutual benefit gains. Pengertian lain menjelaskan bahwa kemitraan adalah 
kolaborasi strategis antara bisnis dan organisasi non profit dimana risiko, sumber daya dan keterampilan dibagi dalam program-program yang menguntungkan masing-masing partner serta masyarakat (Hayati, 2017: 46). Berdasarkan Keputusan Menteri Pertanian Nomor 940 Tahun 1997, menyebutkan bahwa kemitraan adalah kerjasama usaha antara perusahaan mitra dengan kelompok mitra di bidang usaha pertanian.

Menurut Sumardjo et al., (2004) dalam bukunya yang berjudul "Teori dan Praktik Kemitraan Agribisnis", disebutkan bahwa pola kemitraan ada lima, yaitu pola inti plasma, pola sub kontrak, pola dagang umum, pola keagenan, dan pola kemitraan kerjasama operasional agribisnis (KOA).

Menurut (Ad-Dasuqi, 2001: 183), perhimpunan adalah hak (kewenangan) atau pengolahan harta (tasharruf). Adapun menurut (Ibnu Qudamah, 2001: 184), syirkah adalah ketetapan hak pada sesuatu yang dimiliki dua orang atau lebih dengan vara masyhur (diketahui).

Menurut (Antonia, 2001: 90), syirkah atau musyarakah adalah akad kerjasama antara dua pihak atau lebih untuk suatu usaha tertentu yang masing-masing pihak memberikan kontribusi dana dengan kesepakatan bahwa keuntungan dan risiko akan ditanggung bersama. Transaksi musyarakah dilandasi adanya keinginan para pihak yang bekerjasama untuk meningkatkan nilai aset yang dimiliki secara bersama-sama. Semua bentuk usaha yang melibatkan dua pihak atau lebih yang secara bersama-sama memadukan seluruh bentuk sumber daya, baik yang berwujud maupun tidak berwujud. Dalam bahasa ekonomi, hal ini biasa dikenal sebagai joint venture.

\section{Teori Pedagang Tradisional}

Sektor perdagangan adalah sektor yang sangat terbuka dalam arti tidak ada halangan bagi seseorang untuk keluar masuk sektor ini. Perkembangan kegiatan perdagangan melibatkan peran serta masyarakat sebagai konsumen, badan-badan usaha sebagai produsen barang dan jasa maupun pedagang yang berfungsi sebagai penjual kepada konsumen. Khusus untuk usaha kecil dan menengah maka sektor ini membentang di antara transaksi komoditi tradisional sampai transaksi perdagangan komoditas modern.

Di dalam aktivitas perdagangan, pedagang adalah orang atau instusi yang memperjualbelikan produk atau barang, kepada konsumen baik secara langsung maupun tidak langsung. Dalam ekonomi, pedagang dibedakan menurut jalur distribusi yang dilakukan dapat dibedakan menjadi: pedagang distributor (tunggal), pedagang partai besar, dan pedagang eceran. Sedangkan menurut pendangan sosiologi ekonomi menurut Drs. Damsar, MA (Mahkamah Agung) membedakan pedagang berdasarkan penggunaan dan pengelolaan pendapatan yang dihasilkan dari perdagangan dan hubungannya dengan ekonomi keluarga. Berdasarkan penggunaan dan pengelolaan pendapatan yang diperoleh dari hasil perdagangan, pedagang dapat dikelompokan menjadi: 
a. Pedagang profesional yaitu pedagang yang menggunakan aktivitas perdagangan merupakan pendapatan/sumber utama dana satu-satunya bagi ekonomi keluarga.

b. Pedagang semi-profesional yaitu pedagang yang mengakui aktivitas perdagangan untuk memperoleh uang tetapi pendapatan dari hasil perdagangan merupakan sumber tambahan bagi ekonomi keluarga.

c. Pedangang subsitensi yaitu pedagang yang menjual produk atau barang dari hasil aktivitas atas subsitensi untuk memenuhi ekonomi keluarga. Pada daerah pertanian, pedagang ini adalah seorang petani yang menjual produk pertanian ke pasar desa atau kecamatan.

d. Pedagang semu adalah orang yang melakukan kegiatan perdagangan karena hobi atau untuk mendapatkan suasana baru atau untuk mengisi waktu luang. Pedagang jenis ini tidak diharapkan kegiatan perdagangan sebagi sarana untuk memperoleh pendapatan, malahan mungkin saja sebaliknya ia akan memperoleh kerugian dalam berdagang.

Adapun ciri-ciri dari pedagang pasar tradisonal adalah sebagai berikut:

a. Modal yang mereka punya relative kecil. Para pedagang tak mempunyai keberanian mendatangi bank umum untuk memperolah modal, mengingat rumitnya prosedur dan persyaratan yang sulit mereka penuhi. Apalagi kebanyakan dari mereka buta huruf dan tak punya asset sebagai jaminan. Akhirnya mereka berpaling pada rentenir, yang setiap saat mampu memberikan pinjaman dengan cepat, tanpa butuh waktu lama dan proses yang rumit.

b. Biasanya mereka melakukan perdagangan hanya memenuhi kebutuhan saat itu. Maksudnya para pedagang tradisonal biasanya kurang memperhitungkan adanya tabungan masa depan, pendapatan yang mereka dapatkan langsung mereka belikan ke barang dagangan, beli keperluan sehari-hari dan tentunya membayar cicilan hutang.

c. Pendidikan para pedagang relative rendah bahkan buta huruf sehingga mereka kurang melihat prospek masa akan datang, bagi mereka perdagangan yang mereka lakukan selama telah memenuhi kebutuhan sudah cukup. Lebih cenderung memilih melakuan pinjaman kepada rentenir karena prosesnya mudah.

\section{Teori Pembiayaan Produktif}

Pembiaayan produktif sendiri yaitu suatu pembiaayaan yang ditujukan untuk kegiataan memenuhi kebutuhan produksi, sebuah kegiatan untuk peningkatan usaha, baik usaha produksi, perdagangan, maupun investasi (Adiwarman, 2010: 234).

BMT sebagai penyedia pembiayaan produktif, yaitu pembiayaan yang digunakan untuk suatu usaha di bidang sektor riil atau sektor yang nyata terus berkembang dan berproduktivitas seperti kios telepon, kios benda pos, konveksi dan yang lainnya. Tujuannya sendiri untuk memperkenalkan kepada masyarakat luas seiring kemajuan teknologi untuk peningkatan produktivitas hasil para anggota, kemudian mendorong tumbuhnya industri rumah tangga 
atau pengelola hasil, serta mempersiapkan jaringan perdagangan atau pemasaran dan masukan akan hasil produksi, dan pastinya menguntungkan, tidak boleh mengganggu program jangka pendek dengan syarat dikelola dengan sistem manajemen terpisah dan profesional.

Untuk mendukung itu semua terdapat dua jenis kegiatan yang mendasar yang perlu dikembangkan oleh KSPPS BMT Walisongo, yakni sebagai berikut: Pertama, mengumpulkan informasi dan sumber informasi tentang berbagai jenis kegiatan produktif unggulan untuk mendukung usaha kecil dan kelompok usaha anggota di daerah tersebut. Kedua, kegiatan mendapatkan informasi harga dan melembagakan kegiatan pemasaran yang efektif sehingga produk-produk hasil usaha anggota dan kelompok usaha dapat dijual dengan harga yang layak dan memenuhi jerih payah seluruh anggota keluarga yang bekerja untuk kegiatan tersebut.

Kegiatan pembiayaan usaha mikro antara lain sebagai berikut:

a. Pembiayaan mudharabah yaitu pembiayaan total dengan menggunakan mekanisme bagi hasil.

b. Pembiayaan musyarakah yaitu pembiayaan bersama dengan menggunakan mekanisme bagi hasil.

c. Pembiayaan murabahah yaitu kepemilikan suatu barang tertentu yang dibayar pada saat jatuh tempo.

d. Pembiayaan bai' bi tsaman 'ajil yaitu kepemilikan suatu barang tertentu dengan mekanisme pembayaran cicilan.

e. Pembiayaan qard al-hasan yaitu pinjaman tanpa adanya tambahan pengembalian kecuali sebatas biaya administrasi.

\section{METODE PENELITIAN}

Jenis penelitian yang dipakai adalah penelitian kualitatif. Penelitian kualitatif adalah riset yang bersifat deskriptif dan cenderung menggunakan analisis dengan pendekatan induktif. Proses dan makna (perspektif subyek) lebih ditonjolkan dalam penelitian kualitatif. Landasan teori dimanfaatkan sebagai pemandu agar fokus penelitian sesuai dengan fakta di lapangan. Sifat dari jenis penelitian ini adalah penelitian dan penjajahan terbuka berakhir dilakukan dalam jumlah relatif kelompok kecil yang diwawancarai secara mendalam. Responden diminta untuk menjawab pertanyaan umum, dan menentukan persepsi, pendapat, dan perasaan tentang gagasan atau topik yang dibahas dan untuk menentukan arah penelitian. Kualitas hasil temuan dari penelitian kualitatif secara langsung tergantung pada kemampuan, pengalaman, dan kesepakatan dari interview atau responden (Moleong, 2005: 6).

Metode yang dilakukan dalam penelitian ini adalah metode penelitian Deskriptif Kualitatif. Deskriptif Kualitatif adalah metode penelitian yang kadar kajiannya semata-mata ingin mengungkapkan suatu keadaan yang apa adanya (objektif). Kualitatif adalah penelitian yang datanya disajikan dalam bentuk kata-kata yang mempunyai makna.

1. Lokasi Penelitian

Lokasi obyek penelitian yaitu KSPPS BMT Walisongo Mijen. 
2. Sumber Data

Jenis data yang diperoleh dari penelitian ini dibagi menjadi dua jenis, di antaranya ialah:

a. Data Primer

Data primer merupakan data yang diperoleh dari narasumber secara langsung. Data primer tersebut diperoleh dari hasil wawancara dan observasi. Hal-hal yang ditanyakan pada saat wawancara kepada manager (Bapak Nuriyanto) dan marketing (Bapak Heru Setyawan) KSPPS BMT Walisongo Mijen adalah tentang bagaimana bagian pembiayaan yang dijadikan produk unggulan (mudharabah, murabahah, bai' bi tsaman 'ajil) BMT Walisongo Mijen, serta dari 300 nasabah BMT Walisongo penulis mengambil sampel 20 orang pedagang di sekitar pasar Mijen (pedagang buah, ayam, sembako, warung makan, dan lain sebagainya). Hal ini dilakukan agar tidak terjadi penyimpangan atau kesalahpahaman mengenai permasalahan yang penulis bahas. Sedangkan untuk observasi penulis di sini mengamati suasana perilaku kinerja BMT Walisongo, serta mencatatat segala sesuatu yang berhubungan ketiga pembiayaan unggulan (mudharabah, murabahah, bai' bi tsaman 'ajil) di BMT Walisongo Mijen.

b. Data Sekunder

Data sekunder merupakan data yang diperoleh secara tidak langsung. Data tersebut diperoleh dari laporan-laporan maupun referensi bukubuku yang berkaitan dengan BMT Walisongo. Selain itu bisa juga berasal dari media online yaitu situs resmi BMT Walisongo Mijen.

3. Teknik Pengumpulan

a. Observasi

Metode observasi dilakukan dengan cara mengamati kejadian atau kegiatan yang terjadi di KSPPS BMT Walisongo Mijen selama masa penelitian. Kemudian mencatat hasil pengamatan tersebut untuk mengetahui apa yang sebenarnya terjadi.

b. Wawancara

Wawancara merupakan metode pengumpulan data dengan mengajukan pertanyaan kepada narasumber langsung. Dalam penelitian ini penulis melakukan wawancara dengan manajer, marketing, dan beberapa nasabah KSPPS BMT Walisongo Mijen.

c. Dokumentasi

Dokumentasi di sini mempunyai arti metode pengumpulan data dengan menggunakan data-data perusahaan, baik dari laporan perkembangan usaha perusahaan maupun dari data-data lainnya yang dimiliki oleh perusahaan yang dapat dijadikan bukti autentik. 


\section{PEMBAHASAN}

KSPPS BMT Walisongo adalah lembaga keuangan mikro milik UIN Walisongo Semarang yang akan menjadi salah satu pionir lembaga keuangan syariah dengan tujuan untuk membangun dan mengembangkan ekonomi umat. Kantor KSPPS BMT Walisongo terletak di Jl. Saluyo No. 2 Ruko Mijen Makmur Blok B/5, Mijen, Semarang. Letak kantor tersebut strategis karena berada di belakang Pasar Mijen, dekat pemukiman padat penduduk dan ramai pedagang di sekitarnya. Hal ini menjadikan mayoritas nasabah di BMT adalah pedagang di pasar Mijen. Akan tetapi untuk masyarakat awam yang belum mengenal KSPPS BMT Walisongo akan mengalami sedikit kesusahan dalam mencari kantornya karena letak BMT Walisongo yang sedikit masuk ke dalam rukoruko, hal demikian karena letak ruko yang tidak di pinggir jalan.

Dalam perspektif perlembagaannya, UMKM dapat diklasifikasikan menjadi empat kelompok, yaitu:

a. Livelihood Activites, merupakan UMKM yang digunakan sebagai kesempatan kerja untuk mencari nafkah, yang lebih umum dikenal dengan sektor informal. Contohnya pedagang kaki lima.

b. Micro Enterprise merupakan UMKM yang memiliki sifat pengrajin tetapi belum memiliki sifat kewirausahaan.

c. Small Dynamic Enterprise merupakan UMKM yang telah memiliki jiwa kewirausahaan dan mampu menerima pekerjaan subkontrak dan ekspor.

d. Fast Moving Enterprise merupakan UMKM yang telah memiliki jiwa kewirausahaan dan akan melakukan transformasi menjadi usaha besar.

\section{Pembiayaan di BMT Walisongo}

KSPPS Walisongo Semarang di samping melakukan usaha atau kegiatan ekonomi produktif, juga melakukan kegiatan sosialnya guna membantu dan memberdayakan kaum dhuafa. Dengan sistem kerja yakni sebagai berikut:

1. Sistem Satu Arah (Insidental)

Adalah dana masyarakat yang diterima kemudian didistribusikan secara serentak kepada masyarakat dengan skala prioritas mikro ekonomi.

2. Sistem Feed Back

Adalah sistem dimana lembaga pengelola dana masyarakat (BMT Walisongo) berfungsi sebagai fasilitator bagi masyarakat yang membutuhkan pendanaan untuk modal usaha, apabila tercapai keuntungan dari usaha masyarakat yang menggunakan dana tersebut dapat diperoleh laba bersih sebagai pengembangan kas operasional BMT Walisongo.

3. Sistem Pilot Project

Adalah usaha bersama antara BMT Walisongo dan masyarakat berdasarkan prinsip bagi hasil.

Tiga produk pembiayaan KSPPS BMT Walisongo sebagai berikut:

1. Pembiayaan Mudharabah

Akad mudharabah adalah akad kerja sama antara bank selaku pemilik dana (shahibul maal) dengan nasabah selaku mudharib yang mempunyai 
keahlian dan keterampilan untuk mengelola suatu usaha yang produktif dan halal. Penerapan akad mudharabah di KSPPS BMT Walisongo: Anggota/pengusaha mengajukan permohonan kerja sama atau permohonan pembiayaan dengan akad mudharabah. BMT melakukan survey untuk menilai kelayakan penyaluran pembiayaan. Anggota menyerahkan aset sebagai jaminan kelancaran pembayarannya. Anggota dan BMT menyepakati perjanjian kerjasama. Apabila usaha menghasilkan keuntungan, keuntungan dibagi sesuai dengan nisbah yang disepakati. Apabila mengalami kerugian maka kerugian ditanggung sepenuhnya oleh BMT selama kerugian tersebut bukan disebabkan oleh kelalaian anggota, kecurangan, atau pelanggaran kesepakatan.

2. Pembiayaan Murabahah

Murabahah adalah akad jual beli antara bank selaku penyedia barang dan nasabah yang memesan untuk membeli barang dagangan. Bank memperoleh keuntungan yang disepakati bersama. Harga jual bank adalah harga beli dan supplier ditambah keuntungan yang disepakati.

a. Murabahah tanpa pesanan: Anggota mengajukan permohonan pembiayaan murabahah ke BMT dengan menyertakan spesifikasi barang yang diinginkan. BMT dan anggota membuat perjanjian jual beli barang yang dibeli anggota. Anggota melakukan pembayaran sesuai dengan harga yang disepakati di perjanjian.

b. Murabahah dengan pesanan: Anggota mengajukan permohonan pembiayaan murabahah ke BMT dengan menyertakan spesifikasi barang yang diinginkan. BMT membeli barang ke supplier sesuai dengan kriteria yang diinginkan oleh anggota. Supplier menyerahkan barang yang dibeli ke BMT dan anggota melaksanakan akad jual beli. Anggota membayar harga barang sebesar harga beli BMT ke supplier ditambah margin dan biaya-biaya pengadaan barang yang sudah disepakati ketika perjanjian. BMT menyerahkan barang ke anggota setelah anggota menyelesaikan kewajibannya.

3. Pembiayaan Bai' Bi Tsaman 'Ajil

Bai' bi Tsaman 'Ajil merupakan suatu pembiayaan dengan modal keseluruhan dari BMT yang berbentuk barang secara utuh kemudian pembayarannya dilakukan dengan cara mencicil. Penerapan akad Bai' Bi Tsaman 'Ajil di KSPPS BMT Walisongo: Calon nasabah mengajukan permohonan pembiayaan Bai' Bi Tsaman 'Ajil dengan menyertakan persyaratan. CS memeriksa kelengkapan dokumen nasabah. Accounting officer menganalisis, memeriksa kelengkapan dokumen nasabah, lalu men-survey dan mengidentifikasi aset terhadap supplier yang diinginkan nasabah. Jika akad tidak disetujui maka pemberitahuan penolakan pembiayaan dan berkas dikembalikan kepada nasabah. Jika disetujui maka kontrak pembiayaan nasabah dan BMT Walisongo dengan akad Bai' Bi Tsaman 'Ajil. 


\section{Pengaruh Pembiayaan BMT terhadap Usaha Pedagang di Pasar Mijen}

Dari data yang didapatkan penulis, data hasil observasi, dan wawancara ke pihak KSPPS BMT Walisongo dan 20 sampel acak para pedagang tradisional (pedagang buah, ayam, sembako, warung makan, dan lain sebagainya) di Pasar Mijen dari 300-an nasabah yang melakukan pembiayaan aktif di KSPPS BMT Walisongo, didapatkan hasil bahwa 11 orang peadagang mengambil pembiayaan murabahah, 2 orang pedagang mengambil pembiayaan mudharabah, sedangkan 7 sisanya mengambil pembiayaan bai' bi tsaman 'ajil. Menurut salah satu pedagang pemilik warung makan soto pinggir jalan area Pasar Mijen yang mengambil pembiayaan murabahah, berpendapat bahwa pembiayaan yang diperolehnya dari KSPPS BMT Walisongo sangat membantu dikarenakan dana yang diajukan mudah dicairkan yakni berupa peralatan dan perlengkapan dalam membuka usaha warung makan soto tersebut. Selain itu pembayaran angsuran ringan, dalam hal pengembalian pembiayaan ia tidak harus datang ke KSPPS BMT Walisongo melainkan ada petugas yang mengambil uang angsuran tersebut ke lokasi usaha pemilik warung makan soto tersebut. Hal tersebut didukung oleh pendapat 8 pedagang yang mengambil pembiayaan murabahah, 2 pedagang yang mengambil pembiayaan mudharabah, dan 5 pedagang yang mengambil pembiayaan bai' tsaman ajil. Dari 16 orang pedagang yang penulis wawancarai berpendapat bahwa peran BMT Walisongo sangat membantu permodalan mereka dan pelayanan dari petugas KSPPS BMT Walisongo sangat memuaskan serta ramah sehingga mereka merasa terlayani dengan baik. Sebagian besar pedagang di Pasar Mijen baik yang menjadi nasabah atau tidak menjadi nasabah juga mengenal petugas-petugas dari KSPPS BMT Walisongo karena pelayanannya yang ramah dan menggunakan sistem jemput bola.

Sedangkan 4 pedagang lainnya yakni 2 pedagang yang mengambil pembiayaan murabahah dan 2 pedagang yang mengambil pembiayaan bai' tsaman ajil berpendapat bahwa jika persyaratan dalam pengajuan pembiayaan di KSPPS BMT Walisongo tergolong memberatkan, karena ada persyaratan yang mengharuskan adanya jaminan berupa barang (sertifikat atau BPKB).

Usaha untuk mengatasi kekurangan modal pelaku usaha mikro dan kecil adalah dengan melakukan pembiayaan ke BMT Walisongo. Pembiayaan dilakukan dalam rangka untuk meningkatkan perkembangan usaha mikro dan kecil. Perkembangan usaha diukur dengan indikator meningkatnya jumlah pendapatan, laba, barang yang dijual, dan lainnya selama jangka waktu tertentu. Pembiayaan BMT Walisongo diharapkan dapat menjadi solusi terhadap permasalahan modal para pelaku usaha mikro dan kecil dan dapat menjadi sumber tambahan modal sehingga semakin tinggi jumlah pembiayaan yang diberikan maka persepsi perkembangan usaha akan semakin meningkat. Para pedagang di Pasar Mijen serta masyarakat sekitar merasa terbantu dengan adanya prodak yang ditawarkan oleh BMT Walisongo. Terlebih karena sistemnya yang berbeda dibandingkan dengan lembaga keuangan lainnya. Strategi unggulan dari BMT Walisongo yakni dengan menjemput bola ke lapangan, artinya tim marketing datang langsung ke tempat kerja calon 
nasabah khususnya area pasar Mijen yang ingin mengambil pembiayaan. Bukan hanya tim marketing saja, namun hal tersebut juga dilakukan oleh manager BMT Walisongo. Dengan strategi yang berbeda tersebut, nyatanya mampu mendapat simpanan dari nasabah kurang lebih Rp. 14 Juta setiap harinya. Hal tersebut diperoleh baik dari nasabah yang datang langsung ke BMT Walisongo maupun pihak BMT Walisongo yang datang langsung ke lokasi calon nasabah.

\section{SIMPULAN}

Dari hasil penelitian yang telah dijelaskan di atas bahwasanya KSPPS BMT Walisongo adalah lembaga keuangan mikro milik UIN Walisongo Semarang yang akan menjadi salah satu pionir lembaga keuangan syariah dengan tujuan untuk membangun dan mengembangkan ekonomi umat, selain itu memberikan pengaruh yang signifikan kepada masyarakat atau warga sekitar dan juga mampu membantu para pelaku UMKM terutama pedagang tradisional di Pasar Mijen. Selain itu KSPPS BMT Walisongo menggunakan strategi yang berbeda dari yang lainnya sehingga hal itu menjadi daya tarik bagi warga atau masyarakat sekitar melakukan pembiayaan di KSPPS BMT Walisongo khususnya para pedagang tradisional di Pasar Mijen. Pedagang tradisional di Pasar Mijen merasa terbantu akan hadirnya KSPPS BMT Walisongo terlebih dalam hal permodalan usahanya.

\section{DAFTAR PUSTAKA}

Ad-Dasuqi. (2001). Asy-Syarh Al-Kabir Ma'a Ad-Dasuqi, Juz III, hlm. 348, dalam Rachmat Syafei, Fiqh Muamalah. Bandung: Pustaka Setia.

Adiwarman, A. Karim. (2010). Bank Islam Analisis Fiqh dan Keuangan. Jakarta: Raja Grafindo Persada.

Al Arif, M. Nur Rianto. (2017). Lembaga Keuangan Syariah. Bandung: Pustaka Setia.

Anggraeni, Herdiana P, Salahuddin EA, Ranti W. (2013). Akses UMKM Terhadap Pembiayaan Mikro Syariah dan Dampaknya Terhadap Perkembangan Usaha: Kasus BMT Tadbiirul Ummah, Kabupaten Bogor. Jurnal alMuzara'ah Vol. 1 (1). 56-67.

Antonia, Muhammad Syafii. (2001). Bank Syariah: Dari Teori ke Praktik. Jakarta: Gema Insani Press.

Ariani dan Mohamad Nur Utomo. (2017). Kajian Strategi Pengembangan Usaha Mikro Kecil dan Menengah (UMKM) di Kota Tarakan. Jurnal Organisasi dan Manajemen Vol 13 (2). 99-118.

Dewi, Nourma. (2017). Regulasi Keberadaan Baitul Mal Wat Tamwil (BMT) dalam Sistematis Perekonomian di Indonesia. Jurnal Serambi Hukum Vol. 11 (01).

Dewi, Ernanda Kusuma dan Ayu Astari. (2017). Peran Pembiayaan Mudharabah dalam Pengembangan Kinerja Usaha Mikro pada BMT (Baitul Mal Wat Tamwil). Journal Law and Justice Vol. 2 (2). 113-123. 
Hascaryani, Tyas D., Asfi Manzilati, Nurman S. Fadjar. (2011). Metafora Risk and Return Sebagai Dasar Pengembangan Baitul Maal Wa Tamwil Yang Mandiri. Journal of Indonesian Applied Economics Vol. 5 (1).

Hayati, Beti Nur dan Suparjan. (2017). Kemitraan sebagai Strategi Pemberdayaan Masyarakat dalam Program CSR Batik Cap Pewarna Alami di PT. Semen Gresik Pabrik Tuban. Jurnal Sosiologi USK Vol. 11 (1). 46.

Syafei, Rachmat. (2001). Fiqh Muamalah. Bandung: Pustaka Setia.

Ismanto, Kuat. (2015). Pengelola Baitul Maal pada Baitul Maal Wat Tamwil (BMT) di kota Pekalongan. Jurnal Penelitian Vol. 12 (1).

K. Wong C, Fearon G. Philip. (2007). Understanding egovernment and egovernance: stakeholders, partnerships and CSR. International Journal of Quality \& Reliability Management Vol. 24 (9).

LPPI (Lembaga Pengembangan Perbankan Indonesia) Bekerjasama dengan Bank Indonesia. (2015). Profil Bisnis Usaha Mikro, Kecil dan Menengah (UMKM). Jakarta.

Masyitoh, Novita Dewi. (2014). Analisis Normatif Undang-Undang No. 1 Tahun 2013 Tentang Lembaga Keuangan Mikro atas Status Badan Hukum dan Pengawasan Baitul Maal Wat Tamwil (BMT). Jurnal Economica Vol. 5 (2).

Moleong, J. Lexy. (2005). Metodologi Penelitian Kualitatif. Bandung: Remaja Rosdakarya.

Pinbuk Pusat. (2017). Pedoman dan Cara Pembentukan BMT Balai Usaha Mandiri Terpadu. Jakarta.

Prastiawati, Fitriani dan Emile Satia Darma. (2016). Peran Pembiayaan Baitul Maal Wat Tamwil Terhadap Perkembangan Usaha dan Peningkatan Kesejahteraan Anggotanya dari Sektor Mikro Pedagang Pasar Tradisional. Jurnal Akuntansi dan Investasi Vol. 17 (2).

Soemitro, Andri. (2017). Bank \& Lembaga Keuangan Syariah. Jakarta: Kencana.

Suci, Yuli Rahmini. (2017). Perkembangan UMKM (Usaha Mikro Kecil Menengah) di Indonesia. Jurnal Ilmiah Cano Ekonomos, Vol. 6 (1).

Sumardjo, Jaka Sulaksana, Wahyu Aris Darmono. (2004). Teori dan Praktik Kemitraan Agribisnis. Depok: Penebar Swadaya.

Sudarsono, Heri. (2003). Bank dan Lembaga Keuangan Syariah: Deskripsi dan Ilustrasi. Yogyakarta: Ekonisia. 